\title{
Firms Fight Back: Production Networks and Corporate Opposition to the China Trade War
}

\author{
Jieun Lee ${ }^{\dagger}$ and Iain Osgood ${ }^{\ddagger}$
}

\begin{abstract}
The Trump administration's multi-front trade war dramatically escalated with the imposition of extraordinary tariffs on Chinese imports in 2018. Corporate America has responded with a concerted campaign of resistance. We document these efforts through extensive participation in notice and comment and public coalition-building and show that corporate opposition to the trade war derives from reliance on sourcing and production ties to China. In contrast, we find far weaker efforts by anti-trade firms to support the trade war, whether to insulate themselves from import competition or to confront Chinese trade practices. We therefore describe and empirically illustrate the politics of global production networks, and highlight that scholars of trade politics should not neglect opposition to the Trump trade agenda arising from globally integrated firms. Global order in the area of trade hangs in the balance in an ongoing fight between corporate globalism and populist nationalism.
\end{abstract}

${ }^{\dagger}$ PhD Candidate, Department of Political Science, University of Michigan. Haven Hall, 505 S. State St, Ann Arbor, Mich. 48104; leejieun@umich.edu.

${ }^{\ddagger}$ Assistant Professor, Department of Political Science, University of Michigan. Haven Hall, 505 S. State St, Ann Arbor, Mich. 48104; iosgood@umich.edu. 
Donald Trump campaigned on fundamentally altering America's relationship to the global economy, and has followed that path as President. Withdrawal from the TPP and a spate of industry-targeted protectionist measures early in the administration prefigured two highly destabilizing trade conflicts over the future of NAFTA and the imposition of massive tariffs on Chinese imports. The stakes for producers - firms, farmers, industries, and their associations - are incredibly high. Some stand to gain relief from import competition or have cheered the President's confrontation of foreign trade practices; many others are threatened by retaliation on their exports or by disruption of their global design and production networks.

Despite the evident stakes for American producers, and their prominent but anecdotal role in media reporting on the trade conflicts, fundamental questions about their activities in the trade war have not been answered. First, is there significant active support for Trump's protectionism among producers? Second, what is the mix of support for Trump's trade policies, opposition to them, and producers 'watching and waiting' to see if Trump can renegotiate global trade relations in their favor, though they may not prefer his blunt methods? Third, to the extent that clear positions do emerge from producers in the US on Trump's trade war, what are the most important forces driving those positions?

To answer these questions, we focus on perhaps the most important front in the ongoing trade war: the Section 301 case against China and the associated tariffs imposed on Chinese imports. Trade between the US and China has a unique set of characteristics which make it an important site for testing current models of special interest politics around trade. China is the US's largest trade partner, and many US firms and industries are reliant on production offshored to China or inputs sourced from China. Some US industries benefit from significant export opportunities to China, too. These facts are likely to feed opposition to the trade war. On the other hand, the US runs a massive trade deficit with China and inter-industry trade - which contributes to significant industrial reallocation as entire industries thrive or decline depending on their comparative advantage prevails in the bilateral relationship. The China trade war therefore represents a prime opportunity for anti-trade producers to get politically active to secure insulation from foreign competition.

To examine the political activities of firms and industry associations in response to the trade war, we collect original data on two important forms of political action. The first of these are submissions to the United States Trade Representative (USTR) as part of notice and comment; the second is the organization of public coalitions. Both of these forms of activity reveal meaningful interests among firms and industries in trade policy between the US and China, and let us explore the motivation behind participation in these activities through matched data on trade, foreign investment, and other firm and industry features.

These data evince little organized support for Trump's trade war with China among American producers. This suggests that the political motivations behind the trade war lie in other forces, including Trump's long held mercantilist trade outlook and in the value of appeals to economic 
nationalism and populist anti-elitism among Trump's mass supporters. In sharp contrast, we find robust opposition to the section 301 tariffs emanating from American firms and associations. Their efforts are among the largest and most well-organized on any trade issue of the past 25 years. We also find significant, but noticeably smaller, political activity among 'revisers': firms that support Trump's ends of expanding market access, halting dumping/subsidies, and punishing unfair practices regarding investment and intellectual property, but not the means. Still, activity by these forces are simply second order in comparison to the bulk of producers interested in the China trade war, who are deadset against Trump's tariffs.

What has motivated firms and associations to come out in opposition to the trade war? Above all else, we find that Trump's opponents among producers have been motivated by their supply chain linkages with China. These include the ownership of foreign subsidiaries as well as the sourcing of intermediates and final products whether through direct contracting with foreign firms or through intermediaries. At the same time, Trump's trade rhetoric has emphasized his goal of forcing American firms to come home and re-open American factories with American workers. In other words, Trump wants American producers and retailers to reshore sourcing and production which has gone offshore. We therefore argue that the most concise possible summary of Trump's confrontation with corporate America over the China trade is that it is 'the politics of offshoring' on a grand scale, and with as high stakes as any fight over trade since the creation of the WTO.

Our paper therefore contributes to the emergent literature on Trump's trade wars in three ways. First, we collect systematic original data on corporate and industrial political activity surrounding Trump's China trade war. Second, we provide an interpretation of Trump's trade conflict with producers, and while our findings are nuanced, we claim that the trade war is most importantly about offshoring and the politics of global production. Finally, we highlight the critical importance of the conflict between Trump, his anti-trade advisors, and his core supporters, on one hand; and, globalization's corporate proponents and their supporters in Congress and the public, on the other hand. So far this fight has been more intense and witnessed deeper changes to American trade policy than these authors would have ever guessed. But the war is not over, and we predict that trade's proponents are going to remain active and engaged on the issue until they have prevailed or are ultimately defeated.

\section{Trump's Trade War with China}

China is among the US's most important trade partners, so efforts by the Trump administration to fundamentally alter this relationship are likely to provoke a major response from American

producers. So far this response has been described in only anecdotal fashion. To structure our investigation, we describe four key patterns in US-China trade focusing on the importance of 
offshoring, inter-industry trade, imbalances, and trade practices. These patterns have shaped not only the Trump Administration's trade policies toward China, but also provide the foundation for three possible models for understanding producers' attitudes and political activity towards the trade war. These models emphasize the politics of offshoring, trade competition, and trade practices, respectively. Each approach provides a possible interpretation of the major motivations and fault lines among producers amidst the trade war.

\section{Integration, offshoring, adjustment, and imbalances}

The modern era of US-China trade dates to 1978-9 with the initiation of major economic reform under Deng Xiaoping, US recognition of the PRC, and Chinese re-opening of foreign trade. As late as 1987, total US-China trade (measured as the sum of imports and exports of goods only) was still less than $\$ 10$ billion annually, and so less than .20\% as a ratio with US GDP. By 1995, the equivalent ratio was .74\%; by $2005,2.18 \%$; and by $2015,3.28 \%$. The $\$ 600$ billion in annual goods trade between the countries in 2015 was about $10 \%$ of US GDP in the goods sectors, highlighting the importance of the relationship for US tradables producers. China is now regularly the United States' greatest trade partner.

This growth owes to several forces. First, improvements in shipping technologies and logistics made international trade cheaper and the creation of complex global design and production networks feasible (Hummels, 2007; Hausman, Lee and Subramanian, 2013). Second, the creation of the World Trade Organization and subsequent Chinese entry created significant new opportunities for Chinese firms to access US markets and vice versa. Trade expanded as uncertainty around the annual review of China's MFN trade status was eliminated (Wang, 2003). Third, growth in the Chinese economy and improvements in manufacturing productivity, scale, and scope also grew trade between the two nations. Some of these improvements owe to economic forces as growing specialization and industrial-geographic concentration turned China into the world hub for manufacturing (Dean, Fung and Wang, 2011; Long and Zhang, 2012). But many of these changes owe to the continuing process of structural economic reform of the Chinese economy [See Demir and Solingen, this volume].

As a first observation, a critical feature of the US-China trade relationship is that it is big - one of the US's most important bilateral economic relationships. We highlight four further fundamental features of contemporary US-China trade which we expect to shape the special interests politics of trade between the two countries.

The US-China Production Network: The most important feature of contemporary US-China trade is the reliance of US firms on goods manufactured in China. This has occurred through offshore production by US multinationals; production outsourced to Chinese firms through direct contracting for firm-specific inputs or final products; and the sourcing of non-firm-specific inputs or final products from Chinese firms at arm's length (Feenstra and Hanson, 1996; Grossman, Rossi-Hansberg 
et al., 2006; Grossman and Rossi-Hansberg, 2008). As trade barriers fell and the Chinese economy developed, major US corporations seized opportunities to manufacture and source overseas with cheaper labor and inputs and superior knowhow and supply networks (Yeaple, 2006; Baldwin and Okubo, 2014; Ebenstein, Harrison and McMillan, 2015). Key developments in logistics technologies, computerization, and trade administration accelerated this trade, leading not only to bilateral offshoring of production but the knitting together of highly complex multi-country production networks which often feature China as the most important link in the chain, whether in parts sourcing or final assembly [See Zhang, this volume]. The development of global production networks has sharply accelerated specialization, while agglomeration and economies of scale have improved Chinese manufacturing productivity to a remarkable degree (Krugman, 1979; Arndt, 1998; Eckel, 2008).

Inter-Industry Trade and Specialization: A second key feature of US-China trade is the continuing importance of industrial specialization (Xing, 2007; Shen and Gu, 2007). Contemporary global trade among the most-developed countries generally has less industrial specialization in comparison with earlier eras. One way of seeing this is to examine intra-industry trade, wherein countries both export and import varieties of goods in the same industry (Grubel and Lloyd, 1971; Grimwade, 2003). Using the Grubel-Lloyd index of intra-industry trade averaged across 6-digit NAICS industries (where 1 indicates perfect balance in imports and exports, and 0 indicates no intra-industry trade), US industries average .61 with the world excluding China. With China, however, US industries average only .29, indicating that far less trade is of this intra-industry type. Similarly, only $36 \%$ of US industries both import and export more than $\$ 50$ million to China (which is a comparatively small sum given the total volumes of trade). The same figures with Canada, and with the rest of the world, are $64 \%$ and $88 \%$, respectively. Two economic consequences arise from these patterns. First, industries which lack intra-industry trade are either import-competing or export-competing, but not both. Second, greater shares of inter-industry trade induce more pronounced inter-industrial reallocation as a result of trade integration. Competitive industries grow, uncompetitive industries contract or disappear.

Trade Imbalances: A third feature of US-China trade - and one that is connected to the flourishing of both international production networks (Baldwin, 2012; Baldwin and Lopez-Gonzalez, 2015) and the scope of industrial adjustment - is persistent trade imbalances. US-China goods trade was quite balanced in the 1980s; by 1995 and 2005 the deficit had grown to $\$ 33$ billion and $\$ 200$ billion, respectively. In nominal terms, the deficit peaked in 2018 at $\$ 419$ billion, an extraordinary number that contributed significantly to the US's overall trade deficit of $\$ 618$ billion that year. In tandem, China has accumulated a vast share of dollar-denominated foreign currency reserves and Chinese investment in the United States has grown substantially. $16 \%$ of the US federal debt is owed to Chinese bondholders. 
Chinese trade practices and industrial policy: A final key feature of US-China trade is an ongoing dialogue focused mainly on American complaints about Chinese trade practices. During the Bush administration, these criticisms focused mainly on accusations of systematic currency undervaluation, which abated as the renminbi appreciated from 2005 to 2014 (Bown, 2009). In the meantime, concerns about a range of practices of the Chinese state and Chinese corporations related to intellectual property and technology transfer have grown (Liu and Woo, 2018). US business groups cite Chinese intellectual property rights (IPR) infringement as one of the most difficult challenges they face doing business in China. According to a 2013 study by the Commission on the Theft of American Intellectual Property, China accounted for $70 \%$ of global IPR theft, which is estimated to cause annual US economic losses at $\$ 240$ billion. American corporations, and the US trade negotiators, have also complained about continuing barriers to US exports; restrictions on US foreign direct investment; Chinese export subsidies and industrial policy; and industrial espionage (Ahn and Lee, 2011; Lee, 2017).

\section{Trump's trade policy approach}

Into this environment of increasing trade integration between the US and China - and growing offshoring, industrial competition, trade deficits, and trade policy friction - entered Donald Trump. Trump recycled protectionist tropes from previous presidential campaigns (e.g. Ross Perot and Pat Buchanan) but with far more strident anti-trade rhetoric fused to economic nationalism and xenophobic appeals (Irwin, 2017). Nearly as striking as the content is the quantity: candidate and then President Trump has emphasized trade to a remarkable degree in his public speeches. This is illustrated in Figure 1, which shows that the average Trump speech has mentioned trade or tariffs in about $5.1 \%$ of paragraphs (represented by the black dots and the solid black line). ${ }^{1}$ We investigate references to US-China trade specifically in the same figure (represented by the solid gray line). ${ }^{2}$ Discussion of trade with China occupy a remarkable share of President Trump's speeches, appearing in an average of $1.25 \%$ of all paragraphs. This is a strikingly high volume for a specific bilateral relationship in a particular policy domain.

Several themes in Trump's trade policy rhetoric echo the major patterns of the US-China trade relationship described above. First, Trump emphasizes offshoring by American corporations:

...I don't want our companies - and I just insist on it - I don't want our companies moving to other countries, firing everybody, losing these great companies and losing

${ }^{1}$ We downloaded these speeches from https://factba.se/transcripts. We use a set of keywords ('trade','tariff', 'export','import','nafta','usmca','tpp') to identify paragraphs with trade-related speech.

2 Any paragraph which contains one of the words 'china' or 'chinese' and at least one of the words 'tariff','trade','deal', 'deficit', 'import','export','tax', 'barrier', or 'unfair' was coded as being China-trade related. 
Trade Issues in Trump speeches

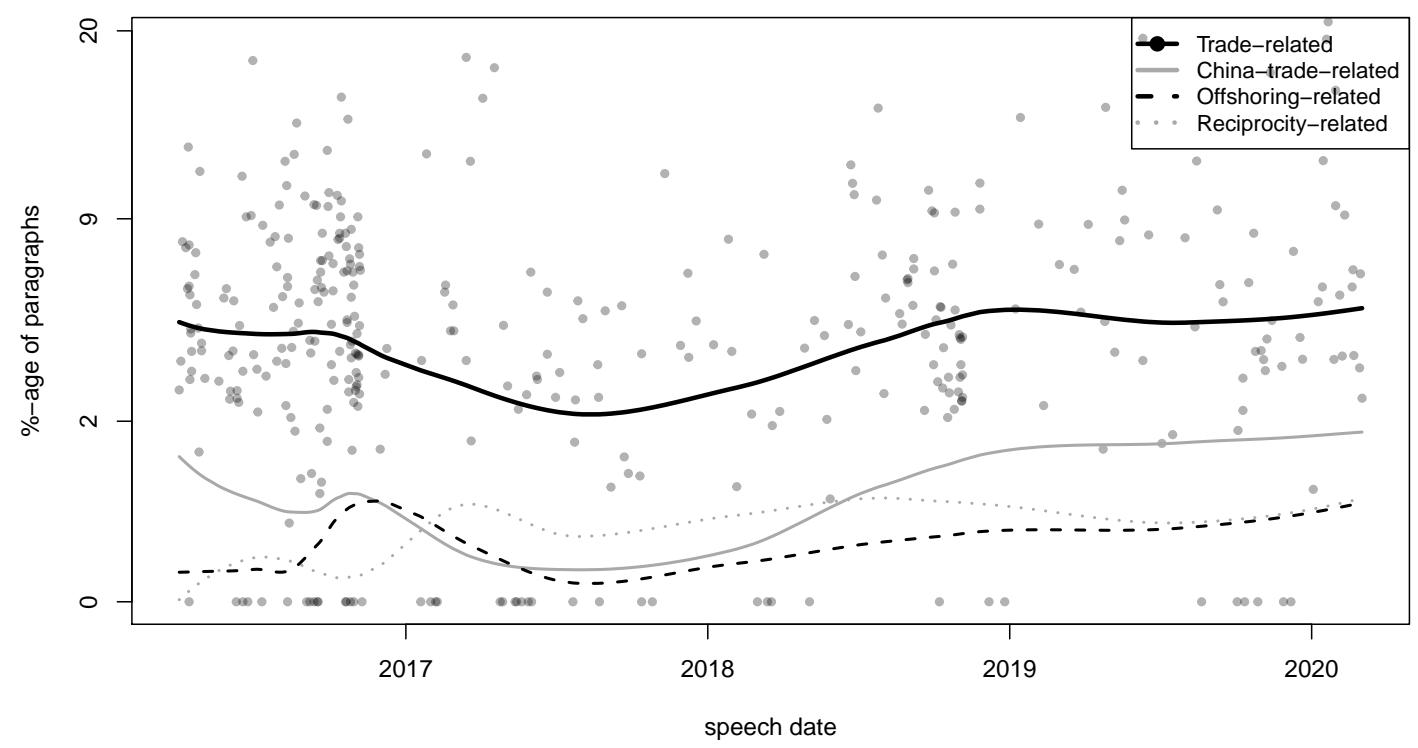

Figure 1: Mentions of trade, trade with China, offshoring, and unfair trade agreements (as a percentage of paragraphs) in President Trump's speeches.

these great jobs, and that's the thing I'm most insistent on with trade deals.

About .5\% of paragraphs (represented over time by the dashed black line) in Trump speeches mention offshoring. ${ }^{3}$ An interesting feature of the speeches in Figure 1 is that discussion of offshoring appears to spike around the 2016 presidential election and in the run-up to the midterms. Discussion of offshoring also increases over the period of intensifying trade conflict with China.

Second, and perhaps more prominent, is the claim that the US's trade partners are 'ripping us off' - as evidenced by large trade deficits - enervating the American economy while destroying workers' livelihoods (Noland, 2018; Fidler, 2017). In this way, Trump is a classic mercantilist (Nelson, 2019) [See Lockwood, this volume]. Trump alternately blames and admires America's trade partners for maintaining high barriers to trade or export subsidies, and then uses those barriers to explain the entirety of the US trade deficit. About .6\% of paragraphs (represented by the dotted gray line) in an average Trump speech mention these reciprocity or fairness issues around trade. ${ }^{4}$

${ }^{3}$ We use the following as key words: 'offshore', 'empty', 'factory','jobs lost','leaving','moving','American jobs', 'bring jobs', and 'lost our companies'. These must be used in paragraphs on trade.

${ }^{4}$ Our key words here are 'reciprocal' and variations, 'fair', and 'advantage'. Again these must be contained in paragraphs about trade. 
A third theme in Trump's rhetoric is the fecklessness and incompetence of US trade negotiators and previous administrations. "Nearly two decades ago, politicians in Washington placed China into the WTO... one of the great catastrophes in the history of our country as far as trade is concerned - between that and NAFTA, you had two real beauties - allowing it to largely do whatever they want to do to the American marketplace..." By comparison, Trump is a superb negotiator and reshoring is gathering pace:

[U]nder the previous administration, they said manufacturing's never coming back. It's gone. You'd need a magic wand. Well we found the magic wand and that's actually that's actually going to be increasing by a lot in the next short while because we have a lot of companies moving in.

Trump, in his own view, is uniquely able to confront and end China's unfair trade policies, and so restore production to the United States while ending trade deficits.

\section{Trump administration's moves on US-China trade}

On August 14th 2017, Trump issued a Presidential Memorandum directing the USTR to determine whether it should launch a Section 301 investigation into China's protection of US intellectual property rights (IPR) and forced technology transfer policies. Four days later, the USTR launched a Section 301 case against China, the first use of Section 301 since 2010. ${ }^{5}$ In March 2018, the USTR released a 215-page study of China's IPR policies that negatively impact US stakeholders, estimating losses to the US economy of at least $\$ 50$ billion per year. Trump signed a Memorandum on Actions by the United States Related to the Section 301 Investigation on that day. The memorandum identified four broad IPR-related policies that justified US action under Section 301. It said China (1) uses foreign ownership restrictions, and various administrative review and licensing processes, to require or pressure technology transfer from American companies; (2) uses discriminatory licensing processes that favor Chinese recipients; (3) directs and unfairly facilitates the systematic investments and acquisitions of US companies, which generates large-scale technology and IP transfer to support China's industrial policy goals, such as the "Made in China 2025" initiative; and (4) conducts and supports cyberintrusions into US computer networks to access their sensitive commercial information and trade secrets.

The Trump administration levied a $25 \%$ tariff on $\$ 34$ billion of Chinese imports in July 2018, which was subsequently applied to a total of $\$ 50$ billion of imports in August. China retaliated in equal measure on US exports. The US and China conducted negotiations on the Section 301

5 Sections 301 through 310 of the Trade Act of 1974, as amended, are commonly referred to as "Section 301." It is one of the principal statutory means by which the US enforces US rights under trade agreements to address "unfair" foreign barriers to US exports. 
investigations, including high-level talks in Beijing and at G20 Summits. After the US prepared a list of $\$ 200$ billion further imports to be taxed at $10 \%$ (and if needed, 25\%), China filed a WTO case against the US on August 14th 2018. These additional tariffs were implemented in September 2018. Bilateral negotiations through the beginning of 2019 were marked by apparent truces and breakthroughs which subsequently unraveled. Trade talks proceeded until May, when the US accused China of suddenly pulling back on a negotiated commitment to implement agreed measures as domestic law. In response, the Trump administration increased tariffs to $25 \%$ on the three tranches of products accounting for $\$ 250$ billion of imports from China and threatened to boost tariffs on nearly all remaining products from China (a further $\$ 300$ billion of imports). In the meantime, China had increased tariffs (at rates ranging from $5 \%$ to $25 \%$ ) on $\$ 110$ billion worth imports from the US. Each side continued to blame the other for backtracking on commitments and undermining prior progress. Relations hit a low when China ceased imports of US agricultural products and the US declared China a currency manipulator in August 2019.

Under pressure from interest groups, politicians, and markets in both countries, China and the US agreed to further talks in September of 2019. Following these talks, held in October, a 'Phase 1' agreement was announced whereby China would increase agriculture imports and respond to other US concerns on IP and currency valuation, while the US would refrain from tariff cuts. The ultimate agreement, signed in January 2020, included larger guaranteed purchases by China and further reductions in tariffs by the United States. The US stopped labeling China a currency manipulator in January.

Over the course of the trade dispute, the proposed Section 301 measures have drawn scrutiny at home and abroad for their potential to damage commerce and the US-China relationship more generally. Of particular interest to us are the role of producers in the trade war. From its inception, the media has reported extensively about efforts among US producers to either contest or support the administration's trade policies. The public campaigns of firms, industry associations, and business groups in opposition to Trump's trade policy moves have often been the hook for stories describing conflict within the United States over trade policy developments. Conflicts between the administration and Congress, and within the White House itself have also generated a steady supply of news stories. These stories remain anecdotal, and there is a need for a more systematic account of the political efforts of producers around trade policy.

In particular, we highlight three key questions for scholars of the special interest politics of trade. First, to what extent have producers supported the trade war, and so can contribute to explaining the Trump administration's trade moves? Clearly Trump's personal views and his supporters' opposition to trade and global cooperation have influenced the initiation of the trade war, but are special interest demands for protection also important? A second related question is what is the mix of positions among American producers in their attitudes towards the China trade war, and to what extent are the competing factions politically active and organized? Producers might be in 
favor of the trade war, opposed to it, or broadly supportive of the end of confronting Chinese trade practices while opposing a tariff war as the means. The mix of these positions among producers is simply not known. A final question is what explains the positions of American firms or industries on Trump's trade wars? As described above, US-China trade is of extraordinary size and has unique features. In what measure have these features affected producers' engagement on the trade war? In order to answer these questions, we organize our thinking around three general approaches to producers' preferences on the trade war.

\section{Three theories of producers' positions on US-China trade}

Each of the facets of the US-China trade relationship described above - offshoring, inter-industry trade, imbalances, unfair trade practices - are likely to feed into producers' responses to the trade war. For purposes of clarity, we focus on describing three stylized models of producers' attitudes and political organization around US-China trade. For each model, we describe the trade forces that are most relevant for the approach and explain the preferences among firms that are most likely to result. In each case, we also consider the implications of these preferences for political organization and action.

We focus in particular on two forms of political action which generate rich data on producers' attitudes toward the trade war. First, firms and associations have submitted detailed comments to the USTR as part of the usual process of notice and comment for new federal rules. Each of the major levies of tariffs described above generated a new request for comments. These comments often contain a position towards specific tariffs or the trade war generally, and may also include the reasoning behind the submitter's position. The comments also include requests for particular goods to be excluded from tariffs or to be included (that is, covered by tariffs). This is a semi-private and often firm-level form of behavior. Second, firms and associations have formed or activated coalitions to take positions on the China trade war. This is a public and collective form of political behavior that provides evidence on firms' and industries' positions and motivations, particularly when matched to firm- and industry-level data on trade. We discuss each of these types of evidence as we describe the empirical implications of our theories below.

The production network model: A first model of the special interests politics of US-China trade holds that producers' reactions are driven by concerns about design and production networks. Trade between the United States and China is dominated by the tight integration of the two economies as part of networks of sourcing and production. The stark differences between the two economies in terms of factor endowments, industry-wide comparative advantage, and varieties of capital lead to enormous benefits from the vertical fragmentation of production. Trade deficits between the two countries are primarily a reflection of the enormous dependence of US firms on sourcing inputs and final production to China. Ongoing trade disputes are bumps in the road that should not 
fundamentally alter the tight integration of the two economics [See Xing, this volume].

Among US producers, the rise of importing from China and offshoring to China therefore creates a large special interest constituency that strongly favors bilateral openness (Gawande, Krishna and Olarreaga, 2012; Manger, 2012; Osgood, 2018; Zeng, Sebold and Lu, 2018). In certain select industries (apparel, retail, toys and electronics manufacturing) virtually every firm large or small is wholly or partly dependent on sourcing from China. In other industries this dependence is less uniform, and so the main beneficiaries from global economic integration are the few very large firms that tend to dominate importing and offshoring. In these cases, offshoring contributes to intraindustry heterogeneity in firms' attitudes toward trade as large firms support the greater openness that smaller firms oppose (Milner, 1988; Amiti and Konings, 2007; Jensen, Quinn and Weymouth, 2015; Osgood, 2017b). Because the firms that benefit from integrated supply chains are larger, they are more adept at individual forms of political engagement (like participating in notice and comment or lobbying). They are also likely to be superior in collective forms of engagement, because smaller groups of larger actors are better able to overcome collective action problems (Osgood, 2020). In sum, the effects of offshoring and importing have been to create and politically empower producers that strongly favor US-China trade links.

What observable implications follow from a model where supply chain integration between the US and China is the dominant driver of special interest politics around the trade war? First, we would expect to see firms opposing the trade war to exceed firms supporting the trade war in notice and comment and collective organization. Second, firms should explicitly identify supply chain considerations as driving their decisionmaking. Third, firms seeking to protect their sourcing from China should heavily request exclusion from tariffs. Coverage of US imports from China by exclusion requests should be large in both absolute terms and relative to requests for inclusions. Finally, we should see that MNCs with Chinese affiliates and industries which extensively source inputs from China should be far more likely to oppose the trade war.

The 'trade competition' model: A second possible model of the special interest politics of USChina trade is that they are driven by the forces traditionally considered in the literature on trade politics: import competition (and the desire for protection) and export opportunities (and the desire for access) (Grossman and Helpman, 1994; Gawande and Bandyopadhyay, 2000). Recall from above that US-China trade is of a more inter-industry than intra-industry character, particularly in comparison with US trade with the world or with other major trade partners like Canada or the EU. US trade with China is also grossly imbalanced and features significant complaints about practices that are likely to intensify import competition (currency undervaluation, subsidies) and defeat export opportunities (expropriation of IP, continuing barriers to trade and investment) [See Shaffer and Gao, this volume].

Industries which face inter-industry trade tend to have coherent positions on trade issues: 
firms in import-competing industries should be uniformly opposed to trade, while firms in exportcompeting industries should support trade (Frieden, 1991; Osgood, 2017a). Since US-China trade is more inter-industry than intra-industry, industries may have fewer internal disagreements and the distributive stakes for industries may be sharper (e.g. import competition will not be balanced with export opportunities). Moreover, because of the US's significant current account deficit with China (and given China's sheer size) support for the trade war ought to be supercharged if ordinary trade competition is driving trade politics. Complaints about Chinese trade practices ought could also fuel support for the trade war. In sum, owing to its scale and concentrated negative effects on particular industries, trade with China provides a best possible opportunity to uncover producer opposition to trade due to import competition. That being said, the literature on US trade politics emphasizes the notable disorganization - individually and collectively - of anti-trade firms in the US (Osgood, 2020). The US-China trade war is therefore a crucial test for whether anti-trade firms in the US can get their act together to coherently support protectionism.

This 'trade competition' model generates four empirical implications which distinguish it from the 'production networks' model described above. First, amidst significant inter-industry trade and enormous trade deficits, it is possible that support for the trade war will be noticeably more prevalent than opposition among producers, or at least that support and opposition will be relatively balanced. Second, firms should mention the need to buffer (unfair) import competition with tariffs if they are import-competing, or the potential for lost sales due to retaliation if they are exportcompeting, as primary drivers of their positions on the trade war. Third, firms should be relatively disinterested in requesting specific exclusions from the trade war but should be quite active in requesting inclusions of their own products. Finally, opposition to the trade war should be restricted to the relatively few industries with concentrated export success in China. Support should come from the many industries facing import competition from China.

The 'revise Chinese trade practices' model: A final model of producers' stances on the trade war starts from the premise that Chinese trade practices are not only unfair but of first order importance. For example, producers who own or are likely to generate significant IP assets should be likely to support the trade war, given that improving IP practices is the primary claimed justification for the Section 301 case. Firms in high-tech industries that have been harmed by forced technology transfer policies, industrial espionage, or IP violations may support the trade war, too. Likewise producers that haven't fully benefitted from opportunities to export to China or to directly invest in China due to barriers to trade and investment should also be supporters of the trade war.

The 'revise Chinese trade practices' model also generates a unique set of empirical implications. First, to the extent that genuine infringements on the rights of US firms are driving the trade war, it should be mainly supported by US firms and industries. We might therefore see clear preferences in support for the trade war across submissions and public organization with a paucity 
of opposing firms and industries. Second, firms should mimic the official justifications of the trade war, particularly the importance of intellectual property protections, in their comments to the USTR. Third, firms should be disinterested in requesting exclusions and inclusions, because their motivation is not to ensure or defeat imports of particular goods, but rather to use tariffs as a pressure tactic to secure Chinese concessions. Finally, support for the trade war ought to particularly emanate from industries that face the highest costs from Chinese trade practices. These might include IP-intensive industries due to claimed Chinese infringements on IP, or high tech industries which are increasingly threatened by Chinese export subsidies and industrial policy.

Summary: With our three stylized models of the special interest politics of the trade war described, we highlight several key points. Our goal is to paint as complete and nuanced portrait of producers' response to the trade war as possible in a single chapter. Elements of each of the above models - and forces that we have not discussed or operating in manners that we have not foreseen - are all active simultaneously. That being said, interpreting the trade war requires one to develop an evidence-based model of the most important concerns of producers and the main drivers of their political activity. There is no guarantee a priori that our evidence will point towards any single interpretation as predominant. But if it does, it helps scholars to understand the most important drivers of special interest trade politics in this critical dispute.

\section{Public Submissions on the Section 301 Case}

We begin our analysis of producers' political activity on Trump's trade war by looking at submissions to the United States Trade Representative concerning the Section 301 case against China. New federal rules or regulations generally must be posted to the federal register where comments (known as 'public submissions') are solicited. These processes are centralized through regulations.gov, which is where we accessed the submissions. The USTR has solicited comments on four separate tariff adjustments as part of the Section 301 case against China, and we analyze documents from three of these. ${ }^{6}$ Each of these requests for comments are organized under a 'docket', and the docket numbers for the cases we examine are USTR-2018-0005, USTR-2018-0018, and USTR-2018-0026.

The notice for USTR-2018-0005 ("China's Acts, Policies, and Practices Related to Technology Transfer, Intellectual Property, and Innovation") was posted on April 6, 2018 under Federal Register number 2018-07119. ${ }^{7}$ The docket concerned a $25 \%$ ad valorem tariff on $\$ 34$ billion in Chinese

\footnotetext{
${ }^{6}$ We do not analyze comments from Docket USTR-2018-0025, which was different in nature. The docket consists of requests for exclusion of particular products only, along with responses from interested stakeholders.

${ }^{7}$ Available from: https://www.regulations.gov/docket?D=USTR-2018-0005.
} 
imports. The list of imports subject to the additional duties was released as part of the docket. The docket received 3212 comments. The notice for USTR-2018-0018 was posted June 202018 with Federal Register number 2018-13248, and covered an additional $\$ 16$ billion in Chinese imports with a $25 \%$ tariff. 8 This docket received 748 comments. Docket USTR-2018-0026 was posted in August 2018, and sought comment on an additional 10\% tariff to be imposed on $\$ 200$ billion in Chinese imports. This notice received 6219 comments. $^{9}$

We examine each public submission to these dockets for evidence on the positions of American producers (corporations, farmers, industry associations, and broader business groups) on the China trade war. Our first step in cleaning these data is to assign an appropriate organization name to the submitter because many submitters do not fill in the 'Submitter name' field on regulations.gov. We then code each submitter as one of 15 organization types. We are only interested in five of these types: corporations (or other firms), farmers, trade associations, peak associations, and coalitions with producer members. We provide separate organization type codings where no name is provided in the submission and we ignore unnamed submissions for this project. We also separately identify 'cut-and-paste' submissions organized among corporate employees and member firms in trade or peak associations, and we do not investigate these non-unique submissions. Finally, it is worth reiterating that a substantial number of submissions come from ordinary citizens (1875 overall), employees communicating through employer-organized campaigns (896), and much smaller numbers from members of Congress, unions, government entities, and NGOs. We do not analyze these here.

Submissions to USTR often include three categories of information. First, submitters often express a position or attitude toward the section 301 tariffs; may state a reason for that position; and may describe the situation of their firm in relation to trade with China (e.g. they are a firm that imports from China or that exports to China). We therefore coded for each of these items. We also coded if submitters stated that Chinese IP practices, the formal justification for the trade war, were relevant to their business. Second, many submitters use their responses to request exclusions of products from the proposed tariffs or inclusions of products under the tariffs. In the absence of other identifying data, we code submitters requesting only exclusions as opposing the section 301 tariffs, while submitters that requested inclusions were coded as supporting the tariffs. Finally, submitters used their comments to request to appear at hearings or to provide post-hearing rebuttals or clarifications.

8 The docket is called "Requests for Comments: Proposed Determination of Action Pursuant to Section 301: China's Acts, Policies, and Practices Related to Technology Transfer, Intellectual Property, and Innovation". Available from: https://www.regulations.gov/docket?D=USTR-2018-0018.

9 "Request for Public Comment Concerning Proposed Modification of Action Pursuant to Section 301: China's Acts, Policies, and Practices Related to Technology Transfer, Intellectual Property, and Innovation." Available from: https://www.regulations.gov/docket?D=USTR-2018-0026. 


\begin{tabular}{|lc|}
\hline & \\
Table 1: Summary of Producers' & Submis- \\
sions to USTR on Section 301 (N=4697) & \\
Position on Section 301 case: & $71.2 \%$ \\
\hline Oppose & $14.4 \%$ \\
Oppose the means, but not the ends & $9.0 \%$ \\
Support & $5.4 \%$ \\
Unstated & \\
Reason for position on section 301 case: & $87.9 \%$ \\
Disturbance to supply chain or other sourcing issue & $4.9 \%$ \\
Threat of Chinese retaliation on exports & $7.9 \%$ \\
Import competition from China & $2.2 \%$ \\
Chinese IP and tech. transfer practices & $30.7 \%$ \\
Are Chinese IP practices relevant: & $2.9 \%$ \\
Not relevant & $66.4 \%$ \\
Relevant & $77.7 \%$ \\
Unstated & $8.5 \%$ \\
Request for exclusion from, or inclusion under, tariffs: & \\
\hline Exclusion & \\
Inclusion & \\
\hline Notes: 4697 submissions from corporations, farmers, trade asso- \\
ciations, peak business associations, and coalitions included from \\
Dockets USTR-2018-0005 (Request for Public Comment Con- \\
cerning Proposed Determination of Action Pursuant to Section \\
301); USTR-2018-0018 (same title as previous); and USTR-2018- \\
0026 (Request for Public Comment Concerning Proposed Modi- \\
fication of Action Pursuant to Section 301). \\
\hline \multicolumn{2}{|c}{} \\
\hline
\end{tabular}

\section{The content of comments}

Our summary of the content in these documents supplied by corporations, farmers, trade associations, and peak business associations is provided in Table 1. As a first observation, the public submissions to the USTR on the China tariffs are incredibly large in comparison with other trade issues. We count 9784 submissions to the USTR from interest groups, producers, and the public across the three dockets we examine. A typical US trade agreement has submissions numbered in the tens or hundreds. Evidently, the stakes of the China tariffs has elicited a profound response from interested stakeholders. Of the nearly 10000 responses, 3985 came from corporations with a clearly identified name who supply unique comments; 607 from trade associations; 91 from peak associations; and 18 from coalitions with producer memberships. ${ }^{10}$ These submissions from producers constitute our sample of 4697.

We find that nearly $71 \%$ of producers that submitted comments expressed clear and unambiguous opposition to the Section 301 case generally or to the tariffs being imposed on China in some specific case (and without any countervailing support for other tariffs). A further $14 \%$ of submitters supported the goal of confronting Chinese practices on trade and investment, but opposed the

\footnotetext{
${ }^{10}$ Another 900 or so corporations submitted comments without names or industries. Around 660 corporations
} submitted copy-pasted comments as part of campaigns organized by industry associations. 
tariffs as the means to pursue that. Of the producers that sent in comments, only $9.0 \%$ expressed support for the Section 301 case or for the specific use of tariffs on some line.

What forces drove producers' opinions on the China tariffs? Overwhelmingly, producers expressed concerns about disturbance to their supply chains or other issues associated with importing goods from China. A full $87.9 \%$ of producers which took a position on the case specifically mentioned these concerns as driving their views. In contrast, the threat of Chinese retaliation on US exports was mentioned only rarely, in $4.9 \%$ of submissions. Another $7.9 \%$ and $2.2 \%$ mentioned Chinese import competition and IP or tech-transfer practices as driving their position. Recalling that the justification for the Section 301 case was China's IP and tech practices, we find that only $2.9 \%$ of respondents say those issues were relevant to their business, while $30.7 \%$ explicitly said those issues were irrelevant and $66 \%$ simply didn't mention Chinese treatment of IP.

Where possible, we also coded firms' and associations' descriptions of their relationship to trade with China. Of the firms where we could code this item, about $51 \%$ reported being (at least in part) US wholesalers, retailers, or distributors that import final goods from China. Another $45 \%$ were US manufacturers or other producers that import inputs or intermediate goods from China or offshored final production to China whether within or beyond the boundaries of their firm. In contrast, only $8.5 \%$ of responders reported competing with Chinese-made imports, and only $3.9 \%$ described themselves as exporters to China.

One final point illustrates the overriding concern of most producers with supply chain issues: $77.7 \%$ of submitters requested that a good be excluded from the Trump administration's tariffs, while only $8.5 \%$ requested that a good be included in the tariffs. This fact does not seem to be entirely driven by the breadth of the tariffs' application. For example, $51 \%$ and $76 \%$ of submissions requested exclusions on Dockets 05 and 18, which covered tariffs on only $\$ 50$ billion in Chinese imports. $17 \%$ and $5 \%$ only requested inclusions on those as part of their submissions. Even by the final docket (USTR-2018-0026), tariffs were under consideration for $\$ 250$ billion of the US's nearly $\$ 550$ billion in imports from China. That is, less than a majority of US imports were set to be covered by tariffs. So there was ample opportunity for firms or industries to seek additional protection by requesting inclusions if they wanted to do so. That does not seem to have happened.

\section{Detailed analysis of exclusion requests}

When submitters request an exclusion or inclusion from the USTR, they generally supplied tariff codes or verbal descriptions of the goods that they would like to be excluded or included. Most of the requesters submitted their exclusions at the Harmonized System 8-digit (HS8) level of detail as requested by the USTR. This is a relatively fine level of disaggregation - the US records around 11000 separate tariffs at this level of aggregation - though 10 digit codes are widely used as well, and many requests came in with these codes as well. We use the 8-digit level as our primary unit 
of analysis for our discussion. Some other submitters made requests at higher levels of aggregation, for example, 6-, 4- or even 2-digit codes. Such requests could naturally cover a broad array of 8 -digit codes. We therefore provide statistics on submitters that made requests at the 8- or 10-digit level, and submitters who made requests at any level of aggregation.

The sheer numbers of requests are remarkable. 3823 of 11111 unique 8-digit codes ended up covered by a request for exclusion. Because some codes are requested multiple times, a total of 25634 codes were separately requested for exclusion at some point. Taking away requests at higher levels of aggregation, we still see that 1938 unique 8-digit codes were specifically requested for exclusion with a total of 14331 total requests. By contrast, only 409 8-digit codes were covered by any request for inclusion and the total number of requests was 1887 , more than a factor of 10 smaller than the number of requests for exclusions.

These dramatic differences are only reinforced when we consider the shares of imports from China that lie in HS8 codes that were requested for exclusion. To examine this point we allocated trade data at the 6 -digit level (the finest possible available) equally across 8 -digit tariff lines. ${ }^{11}$ Strikingly, $90.0 \%$ per cent of all US imports from China received at least one request for exclusion on their 8-digit tariff line. When we only include requests at the 8- or 10-digit level, 59.6\% of US imports from China remain covered by a request for exclusion. The equivalent numbers for requests for inclusion are $20.3 \%$ and $15.3 \%$ respectively. Evidently, import-competing firms were far less active in requesting tariff coverage of the goods they compete with than were importing firms in requesting exclusions for the goods they import.

\section{Who opposes through notice and comment}

As a final complementary piece of analysis, we examine determinants of firms' decision to oppose the China trade war through notice and comment. To do so, we have matched our data on expressed opposition to the trade war via a submission to firm-level data from Orbis and trade data from the US Census Bureau. ${ }^{12}$ From Orbis, we identify whether a firm owns a foreign subsidiary located in China or owns a branch located in China. We also use Orbis to identify the firms' 4-digit NAICS industry. Finally, we use Orbis to draw a random sample of 200,000 goods-producing firms and of 200,000 services-producing firms. ${ }^{13}$

Using the Orbis data on firms' industry codes, we then match our firm-level data to trade data aggregated up to the 4-digit NAICS level. We examine several variables including the exports of a firm's industry; it's related-party imports (a proxy for vertical multinationalization); it's non-related party imports; and a measure of its imported inputs derived using trade data and input-output

\footnotetext{
${ }^{11} 6$-digit HS trade data that cover multiple 8-digit codes were allocated equally across those 8-digit codes.

${ }^{12}$ The trade data available at https://relatedparty.ftd.census.gov/.

${ }^{13}$ This sample was drawn in February 2020, and is original to this paper.
} 
tables. Each of these variables is divided by the relevant 4-digit industries sales, and so should be interpreted as 'intensities' or as measures of trade 'penetration', as when an industry's import exposure is measured as imports as a share of total sales. Note that disaggregated trade data is not available for services firms, so we employ a dummy for whether a service firms' industry is net-exporting at the finest level of disaggregation available. Finally, we employ several dummy variables which are meant to capture especial support or opposition to trade with China owing to its treatment of IP or to its industrial policies more generally. First, we look at whether an industry is IP-intensive as defined in a Department of Commerce report (Blank and Kappos, 2012). Second, we consider whether an industry is high-tech or not, as much of the complaints about IP theft, technology transfer, and industrial espionage have occurred in high tech industries (Branstetter and Foley, 2006).

Using these data, we then examine in Table 2 a series of simple bivariate tests to understand what types of firms have joined these coalitions. For each of the variables, we examine the proportion of firms that have opposed the Section 301 tariffs when the variable is either above its median value (or equal to 1) and below its median value (or equal to zero). We also provide a risk ratio for joining an anti-tariff coalition and include a star to indicate if the risk ratio is distinguishable from 1 at the $\alpha=5 \%$ level. Note that estimates of the percentage chance of submitting comments opposing the trade war are estimated for the subpopulation of large and very large firms (or large/very large firms owning subsidiaries or a branch for the subsidiary and branch variables).

We break our explanations down into three classes. First, we examine whether evidence of foreign production or sourcing is associated with expression of opposition to the trade war with China in submissions. We find strong and consistent evidence of such an association. US firms that own subsidiaries and branches in China are dramatically more likely to send in comments opposing the trade war. Firms located in industries where related-party imports are high and where the sourcing of imports from China is great are also noticeably more likely to oppose the trade war.

Second, we find only mixed evidence that firms located in industries that export to China are more likely to oppose the trade war through this channel, with a strong relationship in the goodsproducing industries but no such relationship in the services industries. This latter non-finding may represent the crudeness of our services trade variable and the many challenges in accurately capturing services trade, however. As for imports, we actually find that industries that face a lot of import competition from China are more likely to have opposed the trade war. This is strikingly inconsistent with standard views of trade politics emphasizing protection-seeking firms, but is explicable if we imagine that many US firms are offshore-outsourcing production to Chinese firms. For example, consider all of the US 'manufacturers' of apparel and toys (really designers, branders, and marketers) that rely heavily on offshoring to China for actual manufacturing.

Finally, we see mixed evidence on the links between IP-intensity and whether firms are less likely to oppose the trade war. In goods-producing industries, firms in IP-intensive industries are 
Table 2: Bivariate analysis of opposition to Section 301 case

\begin{tabular}{|c|c|c|c|}
\hline \multirow[b]{2}{*}{ Variable } & \multicolumn{2}{|c|}{$\%$-age chance } & \multirow[b]{2}{*}{ Ratio $(\mathrm{H} / \mathrm{L})$} \\
\hline & ...when high & ...when low & \\
\hline \multicolumn{4}{|l|}{ Goods-producing firms } \\
\hline \multicolumn{4}{|l|}{ Production networks: } \\
\hline Chinese subsidiary & 15.01 & 7.02 & $2.14^{*}$ \\
\hline Chinese branch & 50.00 & 11.25 & 4.44 \\
\hline Related-party imports & 2.67 & 0.91 & $2.92^{*}$ \\
\hline Imported inputs & 2.41 & 1.29 & $1.87^{*}$ \\
\hline \multicolumn{4}{|l|}{ Trade competitiveness: } \\
\hline Exports & 2.37 & 1.37 & $1.73^{*}$ \\
\hline Imports (not related-party) & 2.53 & 1.20 & $2.11^{*}$ \\
\hline \multicolumn{4}{|l|}{ Revise the status quo: } \\
\hline IP-intensive & 2.09 & 1.47 & $1.42^{*}$ \\
\hline High tech & 2.40 & 1.64 & $1.47^{*}$ \\
\hline \multicolumn{4}{|l|}{ Services firms } \\
\hline \multicolumn{4}{|l|}{ Production networks: } \\
\hline Chinese subsidiary & 12.42 & 5.44 & $2.28^{*}$ \\
\hline Chinese branch & 20.00 & 8.99 & 2.23 \\
\hline \multicolumn{4}{|l|}{ Trade competitiveness: } \\
\hline Net-exporting & 0.39 & 0.62 & 0.62 \\
\hline \multicolumn{4}{|l|}{ Revise the status quo: } \\
\hline IP-intensive & 0.55 & 1.19 & $0.46^{*}$ \\
\hline High tech & 1.10 & 1.01 & 1.09 \\
\hline
\end{tabular}

more likely to oppose the trade war, which is consistent with our findings above that most firms are not that interested in the IP aspects of the trade war. On the other hand, the firms in IP-intensive services industries are somewhat less likely to oppose the trade war. We also see somewhat mixed results using our dummy variable measure for high tech industries.

We summarize our results on the analysis of submissions as the following three findings. First, support for the trade war is muted among producer groups participating in notice and comment, despite the fact that US-China trade is in some ways a best-case scenario for finding such opposition due to the volume, imbalance, and inter-industry character of the trade. Second, we instead find strong evidence of opposition to the trade war both examining expressed positions and the deep coverage of requests for exclusions from the tariffs. For some firms, this opposition is paired with support for the end of confronting Chinese trade practices, but the overwhelming majority simply oppose the tariffs or the trade war more generally without expressing any enthusiasm for its intended ends. Finally, we find an exceedingly clear picture of the primary motivation for opposition to the trade war: firms are opposed to disruption of their sourcing from, and production, in China. We also see some opposition from exporting industries, but supply chain considerations are dominant. Overall, our evidence from notice and comment suggest that an approach focused on production networks should be the dominant model for interpreting the trade war's special interest politics. 


\section{Table 3: Coalition activity in opposition to the Section 301 case against China}

\begin{tabular}{|c|c|c|c|c|}
\hline Group: & Total & Corporations & Trade assocs & Peak assocs \\
\hline Americans for Farmers and Families & 100 & 24 & 71 & 5 \\
\hline Americans for Free Trade letter to Pres. Trump & 157 & 0 & 148 & 4 \\
\hline Coalition of Service Industries & 37 & 27 & 10 & 0 \\
\hline Concerned US businesses' letter to Ways and Means leadership & 107 & 0 & 97 & 5 \\
\hline Farmers for Free Trade & 6 & 0 & 5 & 1 \\
\hline Information Technology Industry Council & 63 & 63 & 0 & 0 \\
\hline Leading footwear companies' letter to Pres. Trump (March 19 2018) & 82 & 82 & 0 & 0 \\
\hline Leading footwear companies' letter to Pres. Trump (May 20 2019) & 173 & 173 & 0 & 0 \\
\hline Reps. of the US business community, letter to Pres. Trump & 46 & 0 & 40 & 3 \\
\hline Retail companies' letter to Pres. Trump & 25 & 25 & 0 & 0 \\
\hline Tariffs Hurt the Heartland & 661 & 517 & 133 & 5 \\
\hline US-China Business Council & 212 & 212 & 0 & 0 \\
\hline US Global Value Chain Coalition & 22 & 9 & 12 & 0 \\
\hline Total unique members & 1279 & 979 & 273 & 17 \\
\hline
\end{tabular}

Notes: Total column refers to total number of members of each column of any type. Corporations, trade associations, and peak associations refer to number of members of those specific types.

\section{Coalition activity on the Section 301 case}

\section{Number and size of coalitions}

Firms opposed to the Section 301 came out in force during notice and comment. Do we see the same pattern in the public ad hoc coalitions that are a recurrent feature of US trade politics (Downie, 2018; Osgood, 2020)? Table 3 reports on 12 unique coalitions that have publicly opposed the China tariffs. Some of these were formed specifically to contest the China tariffs or the Trump administration's broader trade policy moves; others are longer running coalitions. Overall, we find 1279 unique members of these organizations, 979 of whom are individual firms while 273 are industry associations. These are very large numbers compared to recent trade issues. For example, around 400 firms and 250 trade associations publicly supported the Trans-Pacific Partnership in what was the most organized pro-trade campaign since NAFTA.

Several features stand out about the anti-tariff coalitions that we have found. First, several of these appear to have strong motivations to oppose the tariffs due to sourcing their inputs or final products in China. Most obvious of these is the "US Global Value Chain Coalition", which represents primarily apparel producers and stores, as well as their industry associations. Their efforts were matched with a letter put together by the Retail Industry Leaders of America, signed by 25 of the largest retailers in the US. Likewise, footwear companies and retailers have been active in opposing the tariffs in two letters to President Trump from over 170 unique shoe brands and shops. Second, we also see significant participation by agricultural associations, including a large number of state-based associations.

In contrast, we have found not one $a d$ hoc or permanent trade coalition that has supported the China tariffs. That is not so surprising because trade opponents among American firms and associ- 
Table 4: Bivariate analysis of opposition to Section 301 case

\begin{tabular}{|c|c|c|c|}
\hline \multirow[b]{2}{*}{ Variable } & \multicolumn{2}{|c|}{$\%$-age chance } & \multirow[b]{2}{*}{ Ratio $(\mathrm{H} / \mathrm{L})$} \\
\hline & ...when high & ...when low & \\
\hline \multicolumn{4}{|l|}{ Goods-producing firms } \\
\hline \multicolumn{4}{|l|}{ Sourcing: } \\
\hline Chinese subsidiary & 15.22 & 2.31 & $6.58^{*}$ \\
\hline Chinese branch & 50.00 & 9.38 & 5.33 \\
\hline Related-party imports & 0.97 & 0.46 & $2.09^{*}$ \\
\hline Imported inputs & 1.08 & 0.40 & $2.68^{*}$ \\
\hline \multicolumn{4}{|l|}{ Trade competitiveness: } \\
\hline Exports & 0.89 & 0.59 & $1.49^{*}$ \\
\hline Imports (not related-party) & 0.85 & 0.62 & 1.36 \\
\hline \multicolumn{4}{|l|}{ Revise the status quo: } \\
\hline IP-intensive & 0.76 & 0.69 & 1.10 \\
\hline High tech & 0.96 & 0.65 & $1.49^{*}$ \\
\hline \multicolumn{4}{|l|}{ Services firms } \\
\hline \multicolumn{4}{|l|}{ Sourcing: } \\
\hline Chinese subsidiary & 27.33 & 9.62 & $2.84^{*}$ \\
\hline Chinese branch & 0.00 & 13.86 & $0.00^{*}$ \\
\hline \multicolumn{4}{|l|}{ Trade competitiveness: } \\
\hline Net-exporting & 0.83 & 2.33 & $0.36^{*}$ \\
\hline \multicolumn{4}{|l|}{ Revise the status quo: } \\
\hline IP-intensive & 1.24 & 0.69 & $1.80^{*}$ \\
\hline High tech & 3.31 & 0.73 & $4.56^{*}$ \\
\hline
\end{tabular}

ations have been highly disorganized over the past three decades and have only rarely formed public collective organizations. Nonetheless, the very high stakes of the China dispute have apparently been insufficient to rouse trade opponents to collective action.

\section{Who joins opposing coalitions?}

In order to examine the underlying motivations of firms that have joined coalitions publicly opposed to the China tariffs, we again match the coalition-joining firms to firm-level data from Orbis and US trade data. We examine the same variables that are employed above with an identical set of bivariate tests which are reported in Table 4.

We find that ownership of a subsidiary or branch in China is a hugely impactful predictor of joining one of these coalitions. Among only the firms that own foreign subsidiaries, firms that own a subsidiary in China are $13 \%$ more likely to have joined one of these coalitions, a risk ratio of 6.58 compared to the baseline participation of multinational firms. Ownership of a branch has similarly strong predictive effects, although branch ownership in China is quite rare so these results are not reliable evidence. Firms from industries with a lot of related-party imports from China and imported inputs are also significantly more likely to join these coalitions.

In contrast, we do not find that exporting is a consistent driver of opposition to the China tariffs. 
Firms in highly exporting industries oppose the trade war in goods but do not do so in services. As with the analysis of submissions above, again we find that imports increase opposition to the tariffs among goods-producing firms, likely owing to the fact that a lot of those imports represent offshored arm's length production in China. Finally, we do not see any consistent pattern that IP-intensive or high tech industries are less likely to oppose the China tariffs using our, admittedly crude, measures of these concepts. If anything, firms in these industries are more likely to have opposed the trade war.

We summarize our results on the participation of firms in ad hoc coalitions as follows. First, no significant coalition has formed to support the trade war, and no existing ad hoc producer coalition has been involved in supporting the trade war. Second, producers - both firms and associations have come out in force to oppose the trade war through a dozen ad hoc groups. Finally, matching our data on firm memberships in coalitions to data on firm and industry characteristics again show that the motivation for joining these coalitions are relatively simply described. Firms that own foreign subsidiaries in China and firms in industries that rely on outsourced Chinese manufacturing or Chinese inputs are much more likely to have joined a coalition opposing the trade war than other firms. These data therefore corroborate our findings on participation of firms in notice and comment: design and production networks of US firms in China are the most important driver of producers' attitudes and political action in the US-China trade war.

\section{The US Fight over Production Networks}

We now synthesize our findings from the investigation of corporate activity surrounding the Section 301 case. First, we have shown that organized producer support for President Trump's trade war with China has been thin on the ground. This is true both in the realm of public coalitionbuilding - where producer opponents to trade have historically been ill-organized and ineffective - but also in the area of notice and comment, where the barriers to entry are comparatively low. We therefore do not find it plausible that producers' demands for protectionism have acted as an important impetus to Trump's most dramatic trade policy moves. We do of course acknowledge that particular protectionist producers in steel, washing machines, and solar panels have strongly benefited from the trade war. But overall, the origins of the trade are more likely to lie in Trump's personal beliefs or in populist economic nationalist forces than in any strong latent demand for protection across a wide swathe of American producers.

Second, and by contrast, opposition to the Section 301 tariffs has been exceptionally robust and well-organized. The volume of opposing submissions during notice and comment has been unprecedented for a trade issue. Coalitional activity by pro-trade firms and associations has also been remarkable on the issue, surpassing that of any trade issue since the NAFTA debate in 1994. 
Pro-trade firms and associations have come out in force to defend trade openness between the US and China and, in particular, to ensure that the US does not impose significant tariffs on Chinese imports. They have covered almost all US imports from China with a request for exclusion from tariffs.

Third, our results on the drivers of opposition to, and support for, Trump's trade war among producers point strongly in one direction - firms do not want to see their design and production network linkages with China disrupted - although there is some interesting nuance beyond that headline. Firms which own a subsidiary in China are much more likely to come out to oppose the China trade war. Likewise, firms which source inputs or final products from China are much likely to oppose the trade war. Our analysis therefore illustrates the importance of imported inputs and other supply chain considerations that do not flow through the ownership of a foreign subsidiary, for example, through arm's length contracting with foreign producers or through anonymous importing via wholesalers or other intermediaries. The importance of sourcing from China appears over and over across the sources - more than anything else it is the driver of opposition to the China tariffs.

We highlight again at this point three additional facts: the importance of global sourcing in the modern American economy; the prominent role that offshoring has played in President Trump's own political rhetoric; and the evident importance of global sourcing issues in other debates (on a border adjustment tax, the auto tariffs, and the solar panel tariffs). Collectively, these points lead us to our primary conclusion: the most important issue driving the dynamic between President Trump and American producers in the trade war is the overwhelming importance of global supply chains. To a first approximation, their fight is a conflict over the necessity and value of offshoring input sourcing and production of final products. 


\section{References}

Ahn, Dukgeun and Jieun Lee. 2011. "Countervailing duty against China: Opening a pandora's box in the WTO system?" Journal of International Economic Law 14(2):329-368.

Amiti, Mary and Jozef Konings. 2007. "Trade liberalization, intermediate inputs, and productivity: Evidence from Indonesia." American Economic Review 97(5):1611-1638.

Arndt, Sven W. 1998. "Super-specialization and the gains from trade." Contemporary Economic Policy 16(4):480-485.

Baldwin, Richard. 2012. Global supply chains: Why they emerged, why they matter, and where they are going. CEPR Discussion Papers 9103 C.E.P.R. Discussion Papers.

Baldwin, Richard E and Toshihiro Okubo. 2014. "International trade, offshoring and heterogeneous firms." Review of International Economics 22(1):59-72.

Baldwin, Richard and Javier Lopez-Gonzalez. 2015. "Supply-chain trade: A portrait of global patterns and several testable hypotheses." The World Economy 38(11):1682-1721.

Blank, Rebecca M and David J Kappos. 2012. Intellectual property and the US economy: Industries in focus. Technical report. https://www.uspto.gov/sites/default/files/news/ publications/IP_Report_March_2012.pdf.

Bown, Chad P. 2009. "US-China trade conflicts and the future of the WTO." Fletcher F. World Aff. 33:27.

Branstetter, Lee G, Fisman Raymond and C Fritz Foley. 2006. "Do stronger intellectual property rights increase international technology transfer? Empirical evidence from US firm-level panel data." The Quarterly Journal of Economics 121(1):321-349.

Dean, Judith M, Kwok-Chiu Fung and Zhi Wang. 2011. "Measuring vertical specialization: The case of China." Review of International Economics 19(4):609-625.

Downie, Christian. 2018. "Ad hoc coalitions in the US energy sector: Case studies in the gas, oil, and coal industries." Business and Politics 20(4):643-668.

Ebenstein, Avraham, Ann Harrison and Margaret McMillan. 2015. Why are American workers getting poorer? China, trade and offshoring. Technical report National Bureau of Economic Research.

Eckel, Carsten. 2008. "Globalization and specialization." Journal of International Economics $75(1): 219-228$. 
Feenstra, Robert C and Gordon H Hanson. 1996. "Globalization, outsourcing, and wage inequality." The American Economic Review 86(2):240-245.

Fidler, David P. 2017. "President Trump, trade policy, and American grand strategy: From common advantage to collective carnage." Asian J. WTO \& Int'l Health L \& Pol'y 12:1.

Frieden, Jeffry A. 1991. "Invested interests: The politics of national economic policies in a world of global finance." International Organization 45(4):425-451.

Gawande, Kishore, Pravin Krishna and Marcelo Olarreaga. 2012. "Lobbying competition over trade policy." International Economic Review 53(1):115-132.

Gawande, Kishore and Usree Bandyopadhyay. 2000. "Is protection for sale? Evidence on the Grossman-Helpman theory of endogenous protection." Review of Economics and statistics 82(1):139-152.

Grimwade, Nigel. 2003. International Trade: New Patterns of Trade, Production and Investment. Routledge.

Grossman, Gene M and Elhanan Helpman. 1994. "Protection for sale." American Economic Review 84(4):833-850.

Grossman, Gene M and Esteban Rossi-Hansberg. 2008. "Trading tasks: A simple theory of offshoring." American Economic Review 98(5):1978-97.

Grossman, Gene M, Esteban Rossi-Hansberg et al. 2006. "The rise of offshoring: It's not wine for cloth anymore." The New Economic Geography: Effects and Policy Implications pp. 59-102.

Grubel, Herbert G and Peter J Lloyd. 1971. "The empirical measurement of intra-industry trade." Economic Record 47(4):494-517.

Hausman, Warren H, Hau L Lee and Uma Subramanian. 2013. "The impact of logistics performance on trade." Production and Operations Management 22(2):236-252.

Hummels, David. 2007. "Transportation costs and international trade in the second era of globalization." Journal of Economic perspectives 21(3):131-154.

Irwin, Douglas A. 2017. "The false promise of protectionism: Why Trump's trade policy could backfire." Foreign Aff. 96:45.

Jensen, J Bradford, Dennis P Quinn and Stephen Weymouth. 2015. "The influence of firm global supply chains and foreign currency undervaluations on US trade disputes." International Organization 69(4):913-947. 
Krugman, Paul R. 1979. "Increasing returns, monopolistic competition, and international trade." Journal of International Economics 9(4):469-479.

Lee, Jieun. 2017. "China's nonmarket economy treatment and US trade remedy actions." Journal of World Trade 51(3):495-516.

Liu, Tao and Wing Thye Woo. 2018. "Understanding the US-China trade war." China Economic Journal 11(3):319-340.

Long, Cheryl and Xiaobo Zhang. 2012. "Patterns of China's industrialization: Concentration, specialization, and clustering." China Economic Review 23(3):593-612.

Manger, Mark S. 2012. "Vertical trade specialization and the formation of North-South PTAs." World Politics 64(4):622-658.

Milner, Helen. 1988. "Trading places: Industries for free trade." World Politics 40(3):350-376.

Nelson, Douglas R. 2019. "Facing up to Trump administration mercantilism: The 2018 WTO trade policy review of the United States." The World Economy 42(12):3430-3437.

Noland, Marcus. 2018. "US trade policy in the Trump administration." Asian Economic Policy Review 13(2):262-278.

Osgood, Iain. 2017a. "The breakdown of industrial opposition to trade: Firms, product variety, and reciprocal liberalization." World Politics 69(1):184-231.

Osgood, Iain. 2017b. "Industrial fragmentation over trade: The role of variation in global engagement." International Studies Quarterly 61(3):642-659.

Osgood, Iain. 2018. "Globalizing the supply chain: Firm and industrial support for US trade agreements." International Organization 72(2):455-484.

Osgood, Iain. 2020. "Vanguards of globalization: Organization and political action among America's pro-trade firms." Business and Politics pp. 1-35.

Shen, Guobing and Anthony Yanxiang Gu. 2007. "Revealed comparative advantage, intra-industry trade and the US manufacturing trade deficit with China." China $\&$ World Economy 15(6):87103.

Wang, Zhi. 2003. "The impact of China's WTO accession on patterns of world trade." Journal of Policy Modeling 25(1):1-41. 
Xing, Yuqing. 2007. "Foreign direct investment and China's bilateral intra-industry trade with Japan and the US." Journal of Asian Economics 18(4):685-700.

Yeaple, Stephen Ross. 2006. "Offshoring, foreign direct investment, and the structure of US trade." Journal of the European Economic Association 4(2-3):602-611.

Zeng, Ka, Karen Sebold and Yue Lu. 2018. "Global value chains and corporate lobbying for trade liberalization." The Review of International Organizations pp. 1-35. 